\title{
Tough quarantine plans may hurt Ebola fight, Obama administration warns
}

\author{
Michael McCarthy
}

Seattle

The decision by several US states to quarantine health workers returning from west Africa for 21 days could make it harder to end the outbreak of Ebola virus disease, the Obama administration warned over the weekend.

Four states-New York, New Jersey, Florida, and Illinois-have said they will require mandatory quarantine of anyone who has had contact with someone infected with the Ebola virus while in west Africa, including medical personnel who cared for patients.

The governors of New York and New Jersey announced their states' new quarantine polices 24 October, and Florida and Illinois quickly followed. State health officials have broad authority to protect the public's health, and it is unlikely that federal officials could overrule the states' decision.

"By demanding these enhanced measures we are ensuring that any suspected cases are identified quickly and effectively and that proper safeguards are executed," said New Jersey's governor, Chris Christie, a Republican, announcing the new policy.

Currently, under federal rules all travelers from Liberia, Sierra Leone, and Guinea, the three countries most affected by the epidemic, must enter the US through five airports where they are subject to screening. Anyone with fever or symptoms of infection is taken for medical evaluation.

Travelers without symptoms are allowed to continue to their destination but are asked to monitor themselves for 21 days after their last possible contact with someone with Ebola and to report to public health authorities should they develop fever or symptoms of infection. The incubation period for Ebola is 21 days, though in most cases patients have developed symptoms 8-10 days after exposure.

The states acted after a New York physician, Craig Spencer, was admitted to a New York hospital and was given a diagnosis of Ebola virus disease 23 October. Spencer, who works with the charity Doctors Without Borders (Médecins Sans Frontières), had been taking care of patients in an Ebola treatment unit in Guinea. He returned to the US 14 October. Although Spencer had been checking his temperature twice a day and watching for symptoms of the disease, the 33 year old emergency physician had also gone out jogging, gone bowling, eaten at a restaurant, and traveled by subway and cab in the days before his fever appeared.

The idea that someone who was infected with Ebola was traveling freely around the nation's largest city for several days has caused widespread concern, even though health officials have repeatedly said that it was extremely unlikely that Spencer could have been infectious before he developed his fever.

Anthony Fauci, director of the National Institute of Allergy and Infectious Disease, said on the television news program Fox News Sunday, "As we said many times, people without symptoms do not transmit Ebola. We know that. So, guidelines regarding how you handle people from coming back should always be based on the science. And science tells us that people who are asymptomatic do not transmit."

The fear, Fauci said, was that imposing unnecessary and burdensome restrictions on returning health workers may discourage them from volunteering to fight the epidemic in Africa. "The best way to protect us is to stop the epidemic in Africa, and we need those healthcare workers. So, we do not want to put them in a position where it makes it very, very uncomfortable for them to even volunteer to go," Fauci said.

After discussions with officials in the Obama administration, New York's governor, the Democrat Andrew Cuomo, said 26 October that he would be relaxing the state's quarantine policy for health workers, allowing them to stay at home rather than in a medical facility.

But Governor Christie said he had no plans to relax New Jersey's new quarantine rules. "I don't believe when you're dealing with something as serious as this that we can count on a voluntary system. This is government's job. If anything else, the government job is to protect the safety and health of our citizens. And so we've taken this action, and I absolutely have no second thoughts about it," he said.

Administration officials said that new federal guidelines were under development designed to protect the public but not discourage US health workers from going to fight the epidemic in west Africa.

Samantha Power, the US ambassador to the United Nations, said on NBC's Sunday news show Meet the Press, "We need to encourage more; we need many more than are going right now. And we need to find a way when they come home that they are treated like conquering heroes and not stigmatized for the tremendous work that they have done."

Cite this as: BMJ 2014;349:96469

๑ BMJ Publishing Group Ltd 2014 
